UDC 811.111'255.4:821.161.2-141.03=111

\title{
TRANSLATING RELIGIOUS POETRY BY A NON-NATIVE - A TRANSLATOR'S PERSPECTIVE (BASED ON THE TRANSLATION OF THE “AKATHIST HYMN TO OUR LADY IN HOLM ICON GLORIFIED” FROM UKRAINIAN INTO ENGLISH)
}

\author{
Nataliia Dobzhanska-Knight, \\ $\mathrm{PhD}$ in Philology, \\ Assistant Professor of Applied Linguistics Department, \\ Lesya Ukrainka Eastern European National University, \\ Lutsk, Ukraine \\ ndobzhanska@ukr.net
}

Received April, 10, 2018; Accepted May, 4, 2018

\begin{abstract}
The article deals with the peculiarities of translation of an Orthodox Christian poetic akathist prayer from Ukrainian into English by a native speaker of Ukrainian. The author analyses stylistic features of this type of religious discourse as well as processes involved in the translation work. The article dwells on the challenges and facilitating factors of translation. The challenges include a six-rhyme structure combined with a relatively poor selection of rhyming options, the syllable count, a system of word and sentence stresses different from Ukrainian, as well as a limited choice of vocabulary due to the peculiarities of style. The factors which facilitate the translation are also related to the stylistic features of akathist prayers which allow inversions and the use of alternative words and imagery as long as they are in sync with the style and the mood of the Orthodox hymn. The article shows which tools and procedures contribute to a successful result, in particular, rhyming dictionaries and thesauri. To secure the success of a translation performed by a non-native speaker of English, approval of the author and post-translation proofreading by a native speaker is indispensable, which includes both a clergyperson and a professional copyeditor. Consideration of all these factors will contribute to the quality of the translation.

Key words: translating poetry by a non-speaker, religious hymns, translation from Ukrainian into English, challenges of translating religious poetry, tools facilitating translation, post-translation editing, Orthodox Christian texts.
\end{abstract}

\section{Introduction}

Literary translation, in particular, the translation of poetry, has always been among the most challenging areas of translation. There are many reasons the translation of poetry is difficult or problematic. Among such reasons one usually mentions imagery, rhymes, rhythm (metric type), as well as problems in the use of equivalents which may not fit in the metric type or rhyme. 
Literary translation is normally carried out by a native speaker of the target language or a bilingual translator. There is a widespread opinion that it is uncommon or undesirable for a translator to perform translation into a target language if he or she is not a native speaker of the target language. Thus, Tim Parks says that a non-native speaker's vocabulary is inferior to the average native speaker's (Parks, 2014: 79). Sufia Sultana, too, asserts that native translators have better lexical choices, while "non-natives lack literary vitality and linguistic equivalence" (Sultana, 2016: 174). Peter Newmark speaks of the so-called "semi-native speakers" as incompetent translators (Newmark, 2007: 101). There are a number of reasons for such beliefs, and all these reasons could be summed up as the extreme complexity of literary translation which requires a level of knowledge of the target language which could be compared to that of a native speaker. Studies show that inexperienced translators make numerous mistakes in literary translation, even into their native language (Bednárová-Gibová, 2014). We have observed numerous examples of poorly performed translations by non-native speakers of English (Dobzhanska-Knight, 2017). Such translations demonstrate the interference of the translators' native language (i.e., Ukrainian) on all levels: morphological, syntactical, lexical and semantic (Dobzhanska-Knight, 2017). Robert Wechsler, analyzing the state of things in the realm of literary translation, says that being bilingual does not suffice for a translator's successful performance, nor does being a native speaker as are most translators; instead he suggests the idea of collaboration between a native and a non-native translator (Wechsler, 1998). Mona Baker states that being submerged in a source culture and language affects the style of a translator, even if he or she is a native speaker of English (Baker, 2000). Therefore we can assume that non-native speakers of English who are native speakers of a source language will be influenced by their language and culture in their work, which can be both a positive and a negative phenomenon. As a positive phenomenon it will show the understanding of the peculiarities of the original, and as a negative phenomenon it may demonstrate the interference of the source language. Still, in the time of active globalization processes it is important to facilitate translations and enhance their quality by using the human resources available in the country, notwithstanding the non-native character of translators. The goal of this article is to prove that it is possible to perform a good quality translation by a non-native speaker, on condition he or she takes into account the necessary aspects of the work, namely, the challenges and difficulties, factors facilitating the translation, and processes involved, as well as the author's approval, and post-translation editing or proofreading by native speakers.

\section{Akathist hymns, their definitions and peculiarities}

In order to understand the requirements for translating akathist hymn prayers, one should first become acquainted to some peculiarities of this type of religious discourse.

The word 'akathist' comes from Greek and means 'a standing prayer', i.e., a prayer during which a person is standing. It is necessary to mention that there is no agreement or clarity in different sources as to what an akathist hymn is, or when and where such prayers are used. There are also other versions of the word, such as "Akathistus," or "Akathistos." (Akathistos, n. d.). The Merriam-Webster Dictionary 
gives the following definition of the word "Akathistus": "any of several Lenten hymns of the Eastern Orthodox Church sung with the people standing in honor of Christ, the Virgin Mary, or one of the saints." ("Akathistus," n. d., Merriam-Webster, accessed March 10, 2018) The online resource encyclopedia.com, using the information from the authoritative work "The Concise Oxford Dictionary of World Religions 1997," gives the following definition of the word "Akathistos": "Akathistos" (Gk., "not sitting', because it is sung standing). A Greek hymn in twenty-four stanzas in honour of the Virgin Mary. It is sung in Orthodox churches on the fifth Saturday in Lent." (Akathistos, n. d.) We find it necessary, though, to mention that both these definitions are inaccurate. First of all, the use of such hymns is not limited to the Eastern Orthodox Church as there is information that Akathist hymns are used in the tradition of the Eastern Catholic Church as well. ("Akathist Hymn to the Blessed Virgin Mary," n. d., Catholic Online, accessed March 10, 2018) For the second, the use of Akathist prayers is not limited to the period of Lent, as in the Orthodox Christian tradition they are read throughout the year. It is also necessary to add that such prayers are not exclusively "sung," but they can be partly read or chanted. The Greek Orthodox Archdiocese of Australia, as well as many other resources, limits the use of the term "Akathist Hymn" to one particular hymn: "The Akathist Hymn is a profound, devotional poem or chant, which sings the praises of the Holy Mother and Ever-Virgin Mary (Theotokos). It is chanted in all Orthodox Churches throughout the world during the five Fridays in the Great Lent, and constitutes a very concrete spiritual preparation for the Holy Week and Easter Services." (The Akathist Hymn, n. d.) The Greek Orthodox Archdiocese of America clarifies this confusion, by stating that "The Akathist Hymn has proven so popular in the liturgical life of the Church that many other hymns have been written following its format." ("The Akathist Hymn," n. d., Greek Orthodox Archdiocese of America, accessed March 10, 2018).

Akathist hymn prayers started as a part of the Bysantine tradition of worship, as a prayer practiced in the Orthodox Christian world. This tradition spread into other parts of the Christian world, including Kyivan Rus. Later their popularity grew, and a large number of akathist hymns were composed in Russia and Ukraine. Alexander Churkin, for example, says that the akathist hymn became a "mass genre" in the Russian literature in 19-early 20 centuries (Churkin, 2007).

The first Akathist prayers were written in Greek, and they all were in a rhymed form. Later this tradition was abandoned as the prayers were translated into other languages, and this created difficulties in translation. Therefore, the prose form of such prayers was widely accepted in Russian, Ukrainian and other languages, until this recent attempt, when the contemporary Ukrainian author Victor Hrebeniuk pioneered the writing of a poetic Akathist prayer in the Ukrainian language, as well as in the modern Christian world on the whole.

Akathist prayers traditionally consist of 13 short hymns (often called kontakions - from Greek) and 12 refrains (sometimes called ikoses or chants). The short hymns describe an event (i.e., a miracle connected with the icon), and the refrains glorify the Holy Virgin, God, or a saint. In the original Greek tradition, the first akathist hymn was written in Greek iamb, with using rich rhymes. Another important requirement was that all the verses, or stanzas, were arranged in an acrostic according to the Greek alphabet. Another feature of the Akathist hymn is that the short 
hymn should end with the word 'Alleluja,' or other similar words of thanksgiving or glorifying God. Each line of the refrain begins with the same words: "glory to Thee," "Rejoice," or "Hail." The last line is repeated in each refrain. Unlike some other translations, we have chosen more typical English words: "short hymn" and "refrain," as opposed to the Greek words, in order to make the text less confusing and more easily understood by an unprepared English reader. Another reason for choosing the word "refrain," as opposed to "chant," was that we believe that the akathist hymn should be sung, not chanted.

Below are some examples of Akathist prayer.

The Akathist Hymn: "Glory to God for All Things"

\section{Kontakion 1}

Everlasting King, Thy will for our salvation is full of power. Thy right arm controls the whole course of human life. We give Thee thanks for all Thy mercies, seen and unseen. For eternal life, for the heavenly joys of the Kingdom which is to be. Grant mercy to us who sing Thy praise, both now and in the time to come. Glory to Thee, O God, from age to age.

Ikos 1

I was born a weak, defenseless child, but Thine angel spread his wings over my cradle to defend me. From birth until now Thy love has illumined my path, and has wondrously guided me towards the light of eternity; from birth until now the generous gifts of Thy providence have been marvelously showered upon me. I give Thee thanks, with all who have come to know Thee, who call upon Thy name.

Glory to Thee for calling me into being

Glory to Thee, showing me the beauty of the universe

Glory to Thee, spreading out before me heaven and earth

Like the pages in a book of eternal wisdom

Glory to Thee for Thine eternity in this fleeting world

Glory to Thee for Thy mercies, seen and unseen

Glory to Thee through every sigh of my sorrow

Glory to Thee for every step of my life's journey

For every moment of glory

Glory to Thee, $O$ God, from age to age .

("The Akathist Hymn: "Glory to God for All Things," n. d., St. Jonah Orthodox Church 2017)

As we see above, the use of the words 'Thee' and 'Thy', as well as 'illumined,' 'wondrously,' and others, combined with the poetic expressions 'spreading out heaven and earth,' 'mercies, seen and unseen,' 'every sigh of my sorrow,' 'every step of my life's journey' demonstrates the elevated poetic style chosen for this type of literature, which proves its purpose as a prayer of glorification, or as a religious hymn.

Akathist to the Holy Virgin: 


\section{Kontakion 1}

Choir: To Thee, the Champion Leader, we Thy servants dedicate a feast of victory and of thanksgiving as ones rescued out of sufferings, $O$ Theotokos: but as Thou art one with might which is invincible, from all dangers that can be do Thou deliver us, that we may cry to Thee: Rejoice, O Unwedded Bride! (Customarily sung three times at the beginning of the Akathist, once at the end.)

\section{Ikos 1}

Priest: An archangel was sent from Heaven to say to the Theotokos: Rejoice! And beholding Thee, O Lord, taking bodily form, he was amazed and with his bodiless voice he stood crying to Her such things as these:

Rejoice, Thou through whom joy will shine forth:

Rejoice, Thou through whom the curse will cease!

Rejoice, recall of fallen Adam:

Rejoice, redemption of the tears of Eve!

Rejoice, height inaccessible to human thoughts:

Rejoice, depth undiscernible even for the eyes of angels!

Rejoice, for Thou art the throne of the King:

Rejoice, for Thou bearest Him Who beareth all!

Rejoice, star that causest the Sun to appear:

Rejoice, womb of the Divine Incarnation!

Rejoice, Thou through whom creation is renewed:

Rejoice, Thou through whom we worship the Creator!

Rejoice, O Bride Unwedded!

("Akathist to the Holy Virgin," n. d., Orthodox Christian Booklets 2018)

The text of the akathist above shows a more formal style than the previous akathist, with the archaic forms of the verbs (beareth, causest), and the smaller number of neutral words. Akathist Hymn to the Blessed Virgin Mary:

\section{KONTAKION}

Knowing that she was a virgin, the blessed one courageously answered the angel: "Your surprising words seem hard for my mind to accept: how can you speak of a birth that is to come from a conception without seed? And why do you cry, Alleluia?" [RESPONSE]: Alleluia!

\section{SECOND CHANT}

Trying to grasp the meaning of this mystery, the Virgin asked the holy messenger: "How is it possible that a son be born from a virginal womb? Tell me." And he answered her with awe, crying out in these words:

Hail, O hidden Sense of the Ineffable Plan!

Hail, O Belief in Silence That Must Be!

Hail, O Forecast of the Marvels of Christ!

Hail, O Fountainhead of truths concerning Him!

Hail, Celestial Ladder, by whom God came down!

Hail, O Bridge leading earthly ones to heaven! 
Hail, $O$ Wonder, ever-thrilling to the angels!

Hail, $O$ Wound, ever-hurting to the demons!

Hail, O you who gave birth to Light ineffably!

Hail, O you who told no one how it was done!

Hail, $O$ you who surpass the wisdom of the wise!

Hail, O you who enlighten faithful minds!

Hail, $O$ Bride and Maiden ever-pure!

(“Akathist Hymn to the Blessed Virgin Mary," n. d., Catholic Online 2018)

The text above demonstrates a wide use of imagery: "O Bridge leading earthly ones to heaven!", “O Forecast of the Marvels of Christ!", "Celestial Ladder, by whom God came down!", "O Fountainhead of truths concerning Him!" All this imagery comes from the biblical stories, and finds explanation in the Bible. As we see, in the last text the pronoun "you" is used in its modern form.

All the texts above show the absence of rhyme and rhythm, as well as the poetic elevated style. The study of the existing akathist prayers in English gives the translator a clear picture of the requirements of style (necessary or optional), possibilities of word usage, as well as space for creativity, where translators should understand their freedoms and their limits.

Based on the study of these and other akathist prayers, we made a decision about the translation of the Ukrainian word «радуйся», which is used repeatedly at the beginning of every line in every refrain. The literal translation of the word would be "rejoice," but we chose the word "hail," as analogous to the common prayer "Hail, Mary," which sounds in Latin as "Ave Maria," and is a form of greeting or salutation, combined with well-wishing. Therefore, the English word "Hail" is closer to the original Christian prayers. Another reason for choosing this word was to make it follow the rhythm and metric verse of the original, with the first syllable stressed.

\section{Challenges of translating religious poetry}

Translating religious poetry, in particular the Akathist hymn, involves a number of challenges which include, on the one hand, stylistic and vocabulary peculiarities, and on the other hand, the requirements of poetry, which entail observing rhyme and syllable count, as well as the requirements of English grammar, in particular, observing proper word order.

The vocabulary peculiarities of Akathist hymns involve using formal and bookish words, an elevated style, and avoiding the use of colloquial/informal words or expressions. This may involve a challenge for a non-native speaker of English, which will mean spending additional time with different dictionaries, as well as studying numerous examples of usage, especially if a dictionary does not specify the formal character of a word. A native speaker of English has a considerable advantage in this respect as they have sufficient language experience which eventually grows into the 'feeling' of a language, where they sense which context may be improper for a certain word.

At this point we consider it necessary to dwell on some differences between the Ukrainian and English languages which created some of the challenges we faced in the process of translation. 
Among the differences between the two languages, in particular those differences which contributed to the challenge of translation, we observed the following:

1) Differences between the rhyme types in the two languages;

2) A relatively poor choice of rhymes in English;

3) Differences in the word stresses;

4) Differences in the sentence stresses;

5) Articles in English with no articles in the source language (Ukrainian);

6) A relatively free word order in Ukrainian versus a fixed word order in English;

7) Differences in the syllable count.

Now let us analyze each of the enumerated types of challenge as regards to translation.

1) As to the differences between the rhyme types in Ukrainian and English, it is necessary to observe that the "Akathist Hymn to Our Lady in Holm Icon Glorified" uses end rhymes, with the stress vowel rhyming, as well as the surrounding consonants. End rhymes are the only type of rhymes common in Ukrainian (if we do not count the double and triple rhymes), while in English there are also beginning rhymes and first-syllable rhymes which are not normally seen as rhymes by a Ukrainian reader. Speaking of some last-syllable rhymes (like "timber - harbor," or "humanity - zesty" (Rhymer, 2018)), they would not normally be considered rhymes in Ukrainian, as the necessary requirements would not be met. Therefore, we had to limit ourselves only to certain types of rhymes, which inevitably limits a translator's choice of words.

2) According to the famous C. E. Landers book on literary translation, English is a "notoriously rhyme-poor language." (Landers, 2001: 98) The Ukrainian language is richer in rhymes owing to its numerous flexions, or grammatical endings, suffixes, and the free words stress which often falls on the ultimate or penultimate syllable, which increases the possibility of rhyming.

3) The word stress in English is different than in Ukrainian. English is a Germanic language, and all Germanic languages have a common tendency to stress the first or root syllable in a word. In English this tendency is less common than in other Germanic languages, owing to the influence of French and numerous Latin borrowings throughout its history. Finding the right stress pattern is a crucial part of compiling a translated line of a verse.

4) English has a notion of sentence stress, which has to considered in the process of translation. For instance, personal and possessive pronouns, as well as modal words, are normally unstressed. Ignoring this rule may disrupt the rhythmic pattern of a translated line where stressed and unstressed syllables should alternate the way they do in the original text.

5) Articles are a significant aspect of translation, as the translator must take these elements into consideration in the process of syllable count in order to reproduce the original rhythmic pattern. In addition, it is important to remember that these elements are always unstressed, therefore the translator should select the preceding and following words accordingly, observing the stress pattern. Forgetting one article will disrupt the whole pattern in a line, which may affect the whole verse with six and six lines rhymed alternately. Another difficulty is that it is not always obvious from the context which article should be used, as articles do not exist in Ukrainian, and it 
sometimes requires asking the author's opinion as to the intended meaning of a certain word or line.

6) The Ukrainian language has flexions which indicate the relationship between the words in a syntactical unit. The English language is known to have the SubjectVerb-Object word order which can be violated only in certain ways (taking into consideration the rules of inversion). An important feature of the word order is that in English an attribute usually precedes a noun, while in Ukrainian an attribute, though normally it precedes a noun, can take a postposition more often, which would not be considered a rude violation of grammar.

7) There are no diphthongs or triphthongs in Ukrainian, and two consecutive vowels stand for two syllables, while a diphthong or even a triphthong in English stands for one syllable. This should be taken into consideration when building a rhythmic structure of a line, and the second element of a diphthong will not be then counted as a separate syllable. Still, we believe that this rule is not always imperative, given the sung character of akathist hymns.

Another challenge, as was mentioned above, stems from the specific requirements of akathist writing, namely, the imperative use of certain words at the beginning of every verse, creating the acronymic arrangement of the reading, following the Greek alphabet. Thus, Short Hymn 1 had to begin with the word "Invincible", Refrain 1 "Angel", Short Hymn 2 "To see", Refrain 2 "Knowledge" or "Mind", etc.

An additional challenge in the translation from Ukrainian into English has proven to be an easier task for a native speaker of Ukrainian (rather than a native speaker of English), taking into account the numerous changes of transliteration norms since Soviet times. Translators (native speakers of English) may still be heavily influenced by the pro-Russian norms of transliteration which were introduced in the times of the Soviet Union (Romanyshyn, 2009). With Ukraine becoming an independent state, and the Ukrainian language gaining an official status in the country, it will be now politically incorrect to spell, for instance, the capital of Ukraine as "Kiev" (which is still widespread in the English-speaking world). Therefore, we believe that a speaker of Ukrainian is better acquainted with the nuances of such changes, as an incorrect transliteration into English may offend a native speaker of Ukrainian who would see that speakers of English perceive this part of the world as an inseparable satellite of Russia. Still, there are some inconsistencies in transliteration, in the context of which it is important to give our reasons for making certain choices. For instance, we chose the spelling "Holm" as a transliteration from the Ukrainian name "Холм" of the town which means "a hill", and which is part of Poland nowadays. The Polish name is "Chełm", which is a Polish translation of the Ukrainian (Slavic) word (the town was a Ukrainian settlement since the $9^{\text {th }}$ century $\mathrm{AD}$, and in Soviet times was given away to Poland by Stalin). This is why we chose the Ukrainian version of the word. Speaking of transliteration, we chose the English letter " $\mathrm{H}$ " to reproduce the fricative glottal consonant in spelling, while, in contrast to it, the Ukrainian city "Харків" is transliterated as "Kharkiv," according to the Soviet tradition - in order to emphasise the difference between the English sound $[\mathrm{h}]$ and the more fricative Ukrainian sound. But the study of the English spelling tradition shows that the letter combination "Kh" in English will be pronounced as [k], the second consonant being a silent letter (like in the words "khaki," "khan," "khalif," and even 
"Khrushchev" - the name of a Soviet leader, whose name was actually pronounced as [hruft'ov] in Russian). Thus, a native speaker of English, when seeing the spelling "Kholm," will pronounce it as [kolm], which does not reflect its actual pronunciation.

"The Akathist Hymn to Our Lady in Holm Icon Glorified" has a six-rhyme structure, which means every line rhymes with five other lines alternately changing. Taking into account the difficulties concerning rhyme-finding mentioned above, this task will make the translation even more challenging. A most serious challenge was caused by the problem of selecting six words which would rhyme and at the same time reflect the content of the translated lines. This required some sacrifices, as a certain number of syllables could encompass or cover only a limited content, and the rhymed words, being only indirectly related to the ideas of the verses, had to be woven in the translation without distorting the content. This entailed inevitable changes in the process of translation, with new words and imagery being introduced into the text of the target language, and less space remaining (in syllable count) for the words and ideas of the original text. Therefore, we made a constant effort to find shorter words suitable for translation, a search which was aggravated by another type of syllables necessary to add, i.e., articles.

Another stage of the translation process was finding stylistically appropriate words, to reflect the ideas of the original, and at the same time to fit in the required syllable count and stress structure. For this purpose we used several thesauruses which proved to be considerably helpful in this respect. The most challenging part of this stage was to find a stylistically appropriate word with a certain stress pattern, in order to fit in the structure with form-words being mainly unstressed.

With all the difficulties and challenges mentioned above, it seems inevitable that a translator will have to make certain sacrifices in the process of working on the poetic text of the akathist hymn. The sacrifices we made included an imperfect rhyme, changes in the imagery, slight changes in the rhythmic structure (loss of unstressed syllables at the end of the line), and paraphrasing the ideas.

\section{Tools and factors facilitating the translation}

Among the factors which proved to be helpful to the process, besides necessary translator tools (dictionaries), one can mention the peculiarities of the content (with a relative freedom to replace certain notions), the song character of the poetry (where certain syllables can be sung longer), and some stylistic peculiarities which make numerous instances of inversion possible. In addition, the Introduction chapter included in the book explains the content and the meaning of events which are poetically described in each part.

The poetic character of the text, as well as the nature of non-poetic Akathist hymns, makes the understanding of the events described extremely difficult for a person who is not well-informed about the life of a saint or other events associated with a certain relic. Still, this difficulty is not limited to the translation, as the same applies to the original, where without an interpretation and description of the events, the history of the icon, and the miracles described in the Akathist hymn the poetic description might seem confusing. At the same time, it reflects the character of Akathist prayers, when a believer is expected to be well-informed about the deeds of a saint, or other events related to the object of the prayer. This becomes a part of 
preparation for an Akathist prayer for a conscious believer. Therefore, a prose introduction in straightforward language becomes an indispensable part of such a book, in order to facilitate, or even enable, the understanding of its content.

To illustrate this, let us look at a few verses of the Akathist hymn and their explanation in the introductory chapter:

\section{Short hymn 8}

Miracle left a poor servant amazed:

Far at the fair his money was stolen;

Praying to Mother of Holm, he was dazed

Finding the money. Oh, God be extolled! (Hrebeniuk, 2017: 56)

Short hymn 8, Refrain 8. In 1666 the following miracle was recorded. A man 'called Halytsky,' who was a servant of Madam Pyotrovska, went to Lublin with several hundred zlotych, but all the money was stolen. The poor man prayed ardently to Virgin Mary in front of her icon of Holm, and finally he fell asleep. At night somebody put the stolen sum on his chest. (Hrebeniuk, 2017: 8)

As we see above, in the poetic text the story is told, but the form makes its understanding difficult. Thus, the translator tried to use certain key words which would indicate the main elements of the plot: a poor servant, money was stolen and then found after the prayer. The elements of the original which were sacrificed refer to the morning hour and the fact that the money was found, having been left on his chest.

\section{Short Hymn 3}

Violent hordes threaten Holm on the field,

Princesses thy holy icon embrace,

Carrying it to the rampart, they kneel

praying with people of Holm: "God be praised!” (Hrebeniuk, 2017: 46)

Short hymn 3, Refrain 3. At the end of 1240 or at the beginning of 1241 Holm was surrounded by the hordes of Mongolian Tartars. The situation was hopeless. But two princesses, having given a nun's vow in front of the icon, gave an order to take it to the rampart. And, all of a sudden, the little town seemed to the enemy a gigantic one reaching the clowds, and the hordes retreated. Many centuries later people had a proverb, 'The little town of Holm is Heaven-high' (Ibid., 7).

In the text above the additional vocabulary is the word "threaten," and the vocabulary which is present in the original but not in the translation refers to the princesses as "young," and mentions their leaving the palace. There is also a reference to a powerful surge (a crowd of people who went with the princesses).

The replacement of certain vocabulary referring to Christian worship is illustrated in the following examples: від плахи (Hrebeniuk, 2017: 35) (lit. "guillotine, execution") - from death and from chain (Ibid., 65); Мефістофель (Ibid., 33) (Mephistopheles) - the liar and thief (Ibid., 63); Мати Господнього тіла (Ibid., 33) ("Mother of the Lord's body") - Mother of God's human frame (Ibid., 63); Душе усякого діла (Ibid., 33) ("spirit, soul of every deed") - of every good deed living fame (Ibid., 63); щирих прохань легкі Крила (Ibid., 33) ("light Wings of heartfelt requests") - fiery wings, with petitions aflame (Ibid., 63). 
Many of the replacements we made in translation (including the ones with additional lexemes) became possible because they refer to general ideas of suffering and being liberated: Тве́pде у зламанім льодi (Ibid., 25) - from the broken ice saving Shore (Ibid., 55); Втішення в горі та муках (Ibid., 25) - our Solace when grief makes us pale (Ibid., 55); бо знов рятуєш хитливого плоту (Ibid., 25) - Their brittle raft you so kindly restore! (Ibid., 55); Ключ од тісних казематів! (Ibid., 29) Key of Dungeons when sorrows occur (Ibid., 59); від плахи уникнення - Cnaca! (Ibid., 29) - will us from ruin redeem! (Ibid., 59).

Much of the vocabulary in Christian hymns refers to sounds, light and fire, which makes it possible for a translator to alter certain ideas without violating the content:

Радуйся, Сурмо нового пришестя (Ibid., 19)(lit. "trumpet") - Hail, the New Coming's loud heralding Bard (Ibid., 49); Радуйся, Зоре, щуо сяєш так ясно (Ibid., 23) (lit. "shine so brightly") - Hail, Star, thy light is for people unique (Ibid., 53); Нехай не загасне пломінь любові Твій ніжновогня 'ний! (Ibid., 23) (lit. "die out”) May never be dim or bleak Thy Flame of Love, everlasting and sweet! (Ibid., 53); адуйся, Блиску сучасного міста (Ibid., 15) - Hail Lustrous Glamour of city design (Ibid., 45). In the last example the word "modern" was replaced with the imagery associated with a modern city.

There is also an idea of uniformity and a universal character which allows the translator to expand the imagery (e.g., "nobody," "all") by using enumeration: горя не знехтуєш анічийо́zo! (Ibid., 31) - You do not scorn any class, caste or rank! (Ibid., 61); що всіх освічуєш я'сної днини! (Ibid., 15) - Sending thy light to the sinful and blessed! (Ibid., 45).

In certain examples the translator should know the historical context in order to rephrase the text: Радуйся, Матерко Божа пречиста, в о́бразі славна з оселі майстринi! (Ibid.,15) (literally: "glorious in the image from the dwelling of a master" referring to a woman who preserved the icon in her house in Soviet times) - Hail, Mother, thy holy image we find Safely preserved when thy faith was repressed! (Ibid., 45).

As we see from the examples, the changes and deviations from the original are mostly observed in the last part of the line, i.e. the words which we selected for rhyming, and these words represent additional ideas.

Among the translator's tools which proved to be helpful in the process of our work, we should mention the online resources WriteExpress, Rhymer, and RhymeZone. Using these tools one can choose certain types of rhymes, as well as words which have a certain number of syllables. During the next stage of translation we used the Roget Thesaurus and the Oxford Thesaurus, in order to find the needed synonyms of a certain style and with a certain stress pattern.

To sum up, one should say that there are a number of factors which facilitate the translation of poetic Akathist hymns and make it possible even for a non-native speaker of English, notwithstanding the difficulties and challenges of this type of work.

\section{Translation and post-translation editing and proofreading}

Considering the necessary changes in the translated text, as well as the adjustments made in order to create adequate rhymes, which result in the translator's "sacrificing" a large proportion of the vocabulary of the source language, using the 
words matching and fitting the rhymes rather than the equivalents of the units of the original text, the product of such translation has to be approved by the author. This is why we believe that it is important, whenever it is possible, to consult the author and "re-translate" the translation to them literally, in order to receive their approval of the paraphrased forms and altered imagery. It is especially important if the meaning of the original verse is changed or rendered by using slightly or even very different verbal forms.

Here are a few examples where a replacement of the author's imagery was necessary, in order to fit into the syllable-rhyme structure of the verse, and was approved by the author of the original text (the words which have been changed as regards to their meaning (not the form) are selected in bold type and given numbers):

The Ukrainian original:

Радуйся, людства всього́ Жалібнице (1),

зійшла з висот до недуги й моєї! (2)

Радуйся, в го́рі сумирна Ягнице, (3)

щзо до хреста прикипіла душею! (4)

Радуйся, віри коштовна Каплице, (5)

Матір Небесного Архісрея!

Радуйся, мужняя Ти Трудівнище,

“з Тебе ж спасіння”, як мовить Мінея! (8)

Радуйся, Сонце у вікна світлиці, (9)

щчо осяває на творчі ідеї!

Радуйся, щуо Твоя слава ясниться,

вічне Світило, завжди' в апогеї! (Hrebeniuk, 2017 : 35)

The English translation:

Hail, for the whole human race you do mourn (1),

You have descended to wipe all my tears, (2)

Hail, Humble Ewe, always meek to the core (3)

That at the Cross with the soul adheres! (4)

Hail, of the church of our faith Precious Door, (5)

Our heavenly Priest's mother dear! (6)

Hail, valiant laborer forevermore, (7)

You bring the Rescue, the Book said it clear! (8)

Hail, oh Bright Sun shining to our shore, (9)

Giving us sparkling creative ideas!

Hail, for Thy glory forever will soar,(10)

Shining in Apogee year after year! (Ibid., 65)

As we see in the English text, all the changes occur at the ends of the lines, in order to build a six-rhyme structure. The noun (1) has been replaced with the verb, the word which literally means "sickness, illness" (2) was replaced with the image "to wipe one's tears" because these ideas are closely associated - still, the English version has a more general meaning. The meaning "grief" (3) is lost, and instead, the idea of humbleness is strengthened. The difference in (4) reflects changing the past tense (which is close to the present perfect in English) to present simple, which does not change the meaning of the whole phrase. Example 5 shows the narrowing of meaning, changing from "Chapel" to 
"Door of the church." Examples 6 and 7 show additional words and meanings which are not in the original text. Example 8 broadens the name of the Book (in Ukrainian, literally: "Book of Church Services"), and adds emphasis to clarity. Example 9 changes the imagery from "windows of the parlour" to the nautical "shore," which, in our opinion, does not affect the idea much. Example 10 adds the idea of soaring to shining, which, in Christian faith, can be applied to the glory of God.

We insist that consulting a native speaker is imperative for a number of reasons. Firstly, it is a question of performing literary translation by a non-native speaker of a language, where a non-native speaker will lack the professional competence of a native speaker of a language or a bilingual person. The translator may feel a natural hesitation and lack of confidence, being a non-native speaker and therefore lacking the inner 'feel' for a language. On the other hand, the complexity of poetry, as well as the numerous requirements, which summarily make the translation task seem next to impossible, give the translator a certain space and freedom as to the forms of expressing and rendering the author's ideas, with the literal way being impossible in many, if not most, instances. Still, we consider it absolutely necessary to consult a native speaker of English who could be qualified enough to give a professional opinion of the overall quality of the translation and edit where necessary.

Taking into account the specific character of a religious prayer, the translator can feel natural doubts or uncertainty concerning the character of translation, its being proper in the religious sense, as well as its being in accord with the dogmas and doctrines of the Orthodox Church. Without this knowledge, the translator may choose a version of a phrase or a word which is not commonly used by Orthodox believers. Here the translator should observe a proper balance, because there may be a thin line between a cliché, on the one hand (which should be avoided in poetry, as poetry should be original to a certain extent), and an uncommon word or word combination which may seem improper or too unusual for its use in the context or in a given type of text. Therefore, we consider it important to have the translation approved by an editor who would be a native speaker of English and at the same time who would belong to the Orthodox Church, being well-read and well-informed as to the proper style and common expressions used by Orthodox Christian believers. This is especially important regarding the proper choice of a synonym, as a non-native speaker may not be knowledgeable enough to sense the right word which would suit the context, not seem harsh or strange to a native speaker, a church-goer, and especially in order not to insult or offend their religious feelings.

Having been approved by a representative of clergy (a native speaker of English), the text, we believe, should also be approved by another native speaker - a professional editor and copyeditor.

It is indisputable that every piece of literature, before being published, should be approved by a professional editor/copyeditor, to notice and correct certain irregularities of the language and style. We agree with the opinion that "editing a translation is more to do with style, usage, pace, tone and colloquialisms, which are [...] more of a copyeditor's role." (Paul, 2009: 61) For example, it may take a fair amount of time and thus effort even for a professional copyeditor to decide what article is required in a specific context, especially that, with the use of articles being non-existent in the Ukrainian language, it takes a certain degree of interpretation to decide which (if any) article is required in that context, depending on the meaning implied by the author. 
The text under consideration, thus, was subsequently approved by three native speakers of English: a churchgoer (parts of the text) - for the overall approval of the text, a bilingual Orthodox Christian priest, and a professional copyeditor.

\section{Conclusion}

The process of translating the poetic Orthodox Christian prayer, the Akathist hymn to Our Lady of Holm, from Ukrainian into English by a non-native speaker of English, involved a number of complex processes, including the analysis of prose Orthodox Akathist prayers, their syntactical and lexical peculiarities, as well as the comparison of rhyme types in English and Ukrainian. Based on the performed work, one can come to the conclusion that translating religious hymns from Ukrainian to English is not an impossible task for a non-native speaker of the target language. There are a number of factors and tools which enable this process, including the rhyming dictionaries of English, thesauri, as well as the peculiarities of style. The latter, in particular, allow the translator to make inversions, as well as replace certain Christian notions with similar lexemes, as long as they are in agreement with the main ideas and images of Christian faith and worship. The challenges include a six-rhyme structure combined with a relatively poor selection of rhyming options, the syllable count, a system of word accents different from Ukrainian, as well as a limited choice of vocabulary due to the peculiarities of style. Nevertheless, approval of the author and post-translation proofreading by a native speaker is indispensable, which includes both a clergyperson and a professional copyeditor. Taking all these factors into account will contribute to success of the translation.

\section{References}

“Akathistos." n. d. New Catholic Encyclopedia. Encyclopedia.com. Accessed March 10, 2018. http://www.encyclopedia.com/religion/encyclopedias-almanacs-transcriptsand-maps/akathistos

Baker, Mona. 2000. "Towards a Methodology for Investigating the Style of a Literary Translator," Target: International Journal of Translation Studies 12, no 2 (2000): 241-266.

Bednárová-Gibová, Claudia. 2014. "The Dark Side of Literary Translation: An Analysis of Translation Trainees' Performance." In: English Matters V, edited by A. Kačmárová (a Collection of Papers), 4-10. Prešov: Prešovská univerzita.

Čurkin, A. 2007. "Russkij akafist serediny XIX - načala XX veka, kak žanr massovoj literatury." Report presented at XXXVI International philological conference, March 12-17. https://t.co/ij4NLk6SZE

Dobzhanska-Knight, Nataliia. 2016. "Morfolohichna interferentsiya v anhlomovnykh perekladakh (na materiali anhlomovnykh turystychnykh putivnykiv ukrayins'kykh vydavnytstv)". Naukovyy visnyk Mizhnarodnoho humanitarnoho universytetu. Seriya: filolohiya 25, no. 2: 156-161.

—. 2017. "Semantychna interferentsiya $\mathrm{v}$ anhlomovnykh perekladakh (na materiali anhlomovnykh turystychnykh putivnykiv ukrayins'kykh vydavnytstv)" Naukovyy visnyk Skhidnoyevropeys'koho natsional' noho universytetu imeni Lesi Ukrayinky. Seriya: filolohichni nauky 3: 355-362. 
—. 2017. "Vplyv movnoyi interferentsiyi perekladacha na prozorist" ta zrozumilist" perekladiv (na prykladi anhlomovnykh turystychnykh putivnykiv ukrayins"kykh vydavnytstv)" Inshomovna komunikatyvna kul 'tura: spetsyfika, tradytsiyi, innovatsiyi. Papers presented at Interuniversity Scientific and Practical Conference, Luts'k, April 27: 43-47.

—. 2017. "Syntaksychna interferentsiya $\mathrm{v}$ anhlomovnykh perekladakh (na materiali anhlomovnykh turystychnykh putivnykiv ukrayins'kykh vydavnytstv)" Aktual'ni problemy filolohiyi ta perekladoznavstva: zb. nauk. pr. 12: 48-52.

Hrebenyuk, Victor. 2017. "Akafist Presvyatiy Bohorodytsi, u chudotvorniy Kholms'kiy ikoni proslavleniy." Akathist Hymn to Our Lady in Holm Icon Glorified, translated from Ukrainian by Nataliia Dobzhanska-Knight. Lutsk: Initsial.

Landers, Clifford E. 2001. Literary Translation: A Practical Guide. Clevedon: Multilingual Matters, 2001.

Newmark, Peter. 2007. A New Theory of Translation. Sbornik praci filozofické fakulty Brněnské univerzity. Studia minora facultatis philosophicae universitatis Brunensis 13 (2007) Brno Studies in English 33: 101-114.

Parks, Tim. 2014. Translating Style: A Literary Approach to Translation. A Translation Approach to Literature. Second Edition. London: Routledge.

Paul, Gill. 2009. Translation in Practice: A Symposium. Edited by Gill Paul. London: Dalkey Archive Press.

Rhymer. com. 2018. "Narrow Your Search with Six Rhyming Types.” Free Rhyming Dictionary. Accessed March 18, 2018. https://www.rhymer.com/

Romanyshyn, Vasyl, ed. 2009. Kyiv Oblast for Tourists. Guidebook. Translated from Ukrainian by Lidia Volanskyj. Kyiv: Svit uspihy.

Sultana, Sufia. 2016. "Contrastive Linguistic Analysis of Native \& Non-native English Translations of Faiz's Poetry." Journal of Linguistics \& Literature 1, no. 1 (2016): 174-185.

"The Akathist Hymn." n. d. Greek Orthodox Archdiocese of Australia. Paraphrased from Fr. George Papadeas' The Akathist Hymn preceded by The Brief Compline published by Patmos Press, Daytonia Beach, Florida, 1980. Web Archive. Accessed March 10, 2018. https://web.archive.org/web/20061209031328/http://home.it.net.au:80/ jgrapsas/pages/Akat hist.htm

Wechsler, Robert. 1998. Performing Without a Stage: The Art of Literary Translation. Northhaven: Catbird Press, 1998. 